\title{
BRIEF COMMUNICATION OF ASSESSMENT OF CLINICAL PRACTICE REGARDING PHARMACOLOGICAL TREATMENT OF EPILEPSY: A SURVEY OF NEUROLOGISTS IN REPUBLIC OF MACEDONIA
}

\author{
Emilija Cvetkovska $^{1}$, Igor Kuzmanovski ${ }^{1}$, Bojan Boshkovski ${ }^{2}$ \\ ${ }^{1}$ University Neurology Clinic, Medical Faculty, Ss Cyril and Methodius University, 1000 Skopje, \\ R. Macedonia \\ ${ }^{2} 8^{\text {th }}$ September City General Hospital, Skopje, R. Macedonia \\ Corresponding Author. University Neurology Clinic, Medical Faculty, Ss Cyril and Methodius University, \\ Vodnjanska str. 17, MK-1000, Skopje, R. Macedonia; Tel: +389 (0)2 31473 11, Fax: +389 23211091 ; \\ E-mail: emilicvetkovska@gmail.com
}

\begin{abstract}
A questionnaire of 15 items was developed in order to evaluate clinical practice regarding pharmacological treatment of epilepsy among adult neurologists in R. Macedonia. It was mailed to 30 practising neurologists, 24 answered (80\%). Half of them administer AED after a first unprovoked seizure considering EEG and MRI, while others usually wait for a second one before introducing treatment. Discontinuation of treatment should be individualized. Carbamazepine and lamotrigine are the most frequently prescribed first-line drugs for partial seizures; second choices include a number of older and new generation AEDs. For generalized tonic-clonic seizures, absences, myoclonic, mixed or undetermined seizures, valproate is by far the most commonly used AED. The survey showed that prescription patterns are in accordance with current evidence about the spectrum of efficacy of individual AEDs in different types of seizures. Yet some results are a cause of concern and continuous education of the neurological community on AED treatment of epilepsy is needed.
\end{abstract}

Key words: neurologist, survey, epilepsy, pharmacological treatment, antiepileptic drugs.

\section{Introduction}

The ILAE/IBE/WHO report on epilepsy in Europe, launched 2010, identifies a series of problems and challenges in appropriate care for people with epilepsy, one of the most important being that professionals involved in the treatment of patients with epilepsy sometimes do not have sufficient specialized knowledge of the condition [1]. A survey initiated from the Commission on European Affairs assessing the provision of epilepsy care in Europe identified insufficient professional education and knowledge about epilepsy as crucial all across $\mathrm{Eu}-$ rope [2]. Specialization of a medical doctor as a neurologist in a field as specific as epileptology and the expertise that is required to deal with other than the most straightforward cases is very often lacking [1].

The aim of the study was to evaluate clinical practice toward pharmacological treatment of epilepsy among adult neurologists in R. Macedonia.

\section{Methods}

A 15-item questionnaire was developed covering initiation and termination of antiepileptic drug (AED) therapy, preferable drugs used as first-line and alternative choice in different types of seizures (partial seizures in young and older adult, GTCS, myoclonic seizures, absences, multiple types or undetermined type of seizures) as well as minimal and maximal do- 
ses for each drug used. For initiation of AED therapy after the first unprovoked seizure several possibilities were offered: 1 . No, one seizure is not epilepsy, waiting for a second seizure; 2. Yes, considering EEG, MRI and other investigations; 3. Only if it is GTCS; 4. Yes, every seizure is potentially dangerous for the patient. Discontinuation of AED included: 1. Individualized (considering syndrome, etiology);
2. After 1 to 2 years without seizures; 3 . After 3 to 5 years without seizures; 4 . After a more than 5 years seizure-free period; 5 . Never.

Usually used first-line and alternatives if the first is not effective or not tolerable in the type of seizure; all available AEDs were listed (Table 1). The questionnaire was mailed to 30 adult neurologists in three different hospitals in R. Macedonia.

Table 1

Available antiepileptic drugs (AED), mode of prescription, range of minimal and maximal daily doses and mean daily minimal and maximal dose*

\begin{tabular}{|c|c|c|c|c|c|}
\hline AED & $\begin{array}{c}\text { Mode of } \\
\text { perscription** }\end{array}$ & $\begin{array}{l}\text { Minimal daily } \\
\text { dose mg/day }\end{array}$ & $\begin{array}{c}\text { Mean minimal } \\
\text { daily dose } \\
\text { mg/day }\end{array}$ & $\begin{array}{l}\text { Maximal daily } \\
\text { dose mg/day }\end{array}$ & $\begin{array}{c}\text { Mean maximal } \\
\text { daily dose } \\
\text { mg/day }\end{array}$ \\
\hline Carbamazepine & EDL & $200-400$ & 300 & $1200-1600$ & 1400 \\
\hline Valproic acid & EDL & $300-500$ & 350 & $950-2500$ & 1700 \\
\hline Lamotrigine & EDL & $25-50$ & 45 & $150-500$ & 350 \\
\hline Topiramate & EDL & $25-100$ & 55 & $150-400$ & 350 \\
\hline Oxcarbazepine & $\mathrm{SP}$ & $300-600$ & 450 & $1200-2400$ & 1700 \\
\hline Levetiracetam & $\mathrm{SP}$ & $250-1000$ & 750 & $1250-3000$ & 2300 \\
\hline Ethosuximide & EDL & $250-500$ & 350 & $750-1500$ & 1000 \\
\hline Clonazepam & EDL & $0,5-1,5$ & 1 & $6-8$ & 6,5 \\
\hline Phenobarbiton & EDL & $50-100$ & 75 & $100-200$ & 150 \\
\hline Diazepam & EDL & & & & \\
\hline Gabapentin & not in EDL & $300-900$ & 500 & $900-3600$ & 1600 \\
\hline Pregabalin & not in EDL & & & & \\
\hline
\end{tabular}

* Question about doses was not completely answered in half of questionnaires.

** Essential drug list (EDL), Special prescription (SP) fully reimbursed only for refractory epilepsy.

\section{Results}

Answers were obtained from 24 neurologists, a response rate of $80 \%$. Half of the neurologists would administer AED after a first unprovoked seizure considering EEG, MRI and other investigations, while others usually wait for a second seizure before introducing treatment.

According to most of the neurologists, discontinuation of the treatment should be individualized, taking account of the syndrome and its etiology (58\%), some would do this after a seizure-free period of 3-5 years $(21 \%)$ or a seizure-free period of more than 5 years $(21 \%)$.

The most commonly prescribed AEDs in partial epilepsy were carbamazepine and lamotrigine, followed by topiramate, valproate, levetiracetam and oxcarbazepine (Figure 1). By contrast, valproic acid was the most frequently prescribed AED in generalized tonic-clonic sei- zures and in undetermined or mixed types of seizures. The second most prescribed AED and usual second choice if valproate was inadequate was lamotrigine, followed by a wide range of other AEDs: carbamazepine, topiramate, levetiracetam, phenobarbital, even diazepam (Figure $1)$. The utilization pattern of AEDs in myoclonic seizures was to some extent similar: valproate dominated, lamotrigine followed, and then topiramate and clonazepam in decreasing order (Figure 1). In absences valproate was also prescribed by far the most; other AEDs included ethosuximide, lamotrigine, and surprisingly carbamazepine and oxcarbamazepine in some percentage (Figure 1).

The mean of minimal and maximal prescribed daily dosages of individual AEDs are shown in Table 1. 


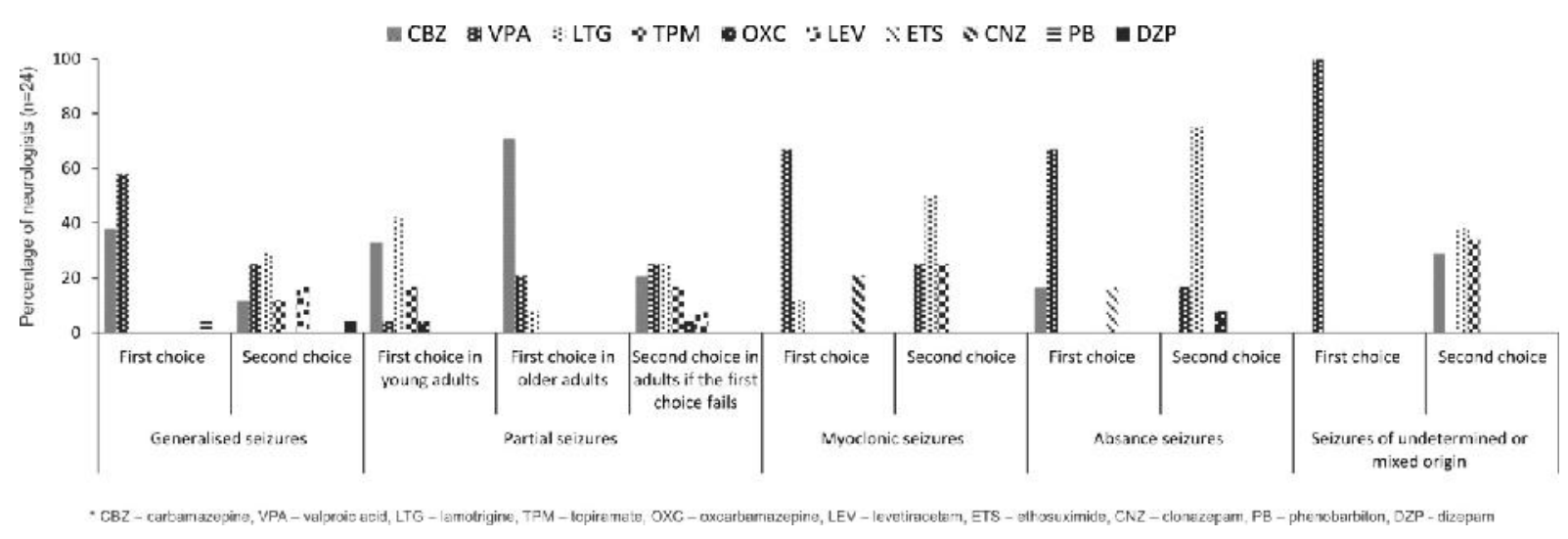

Figure 1 - Pattern of utilization of AED in different type of seizures among adult neurologists in R. Macedonia*

\section{Discussion}

Initiation and termination of antiepileptic treatment should be individualized according to the majority of answers, which is in keeping with existing evidence $[3,4,5,6,7]$. The results of our survey indicate that patterns of AED utilization follow the current recommendations regarding seizure type $[8,9,10,11]$. Carbamazepine, lamotrigine and topiramate dominated in the prescription pattern for partial epilepsies, which is consistent with evidence that these agents are particularly useful in the treatment of partial seizures $[8,9,10]$. Among patients with generalized and in mixed and/or undetermined seizures, the ranking of the most frequently prescribed AEDs was comparable with current recommendations, except for a lower utilization of levetiracetam [12, 13, 14] Valproate dominated, which could be expected in view of its broad spectrum of activity against all seizure types [15] and references it that should remain the drug of first choice for many patients with generalized and unclassified epilepsies [16]. Overall, second generation AEDs were quite widely prescribed, lamotrigine and topiramate were extensively used; lower exploitation of levetiracetam is due to its special prescription (fully reimbursed only for refractory epilepsy).

Surprisingly, carbamazepine and oxcarbazepine were considered to some extent as treatment options for absences; both being narrow-spectrum AEDs which appear to be the major causes of seizure aggravation in absence epilepsies [17, 18, 19]. The explanation might be that adult neurologists relatively rarely deal with absence seizures and are quite unfamiliar with their treatment.
Mean minimal and mean maximal doses for prescribed drugs tend to be lower and a small number would administer maximal tolerated doses.

Although the study has limitations (sex differences in the prescription pattern were not examined), it gives substantial information about the pattern of pharmacotherapy with AEDs.

In conclusion, utilization of individual AEDs was mostly in accordance with international guidelines and recommendations. However, some data indicate that additional education is needed and increasingly important for improvement of the pharmacological therapy of epilepsy.

\section{REFERENCES}

1. Epilepsy in the WHO European Region: Fostering Epilepsy Care in Europe 2010. http://www.ibe-epilepsy.org/downloads/EURO\%20 Report\%20160510.pdf

2. Malmgren K, Flink R, Guekht AB, et al. ILAE Commission of European Affairs Subcommission on European Guidelines 1998-2001: The provision of epilepsy care across Europe. Epilepsia. 2003; 44(5): 727-731.

3. Wiebe S, Tellez-Zenteno J, Shapiro M. An evidencebased approach to the first seizure Epilepsia. 2008; 49 (Suppl. 1): 50-57.

4. Marson A. When to start antiepileptic drug treatment and with what evidence? Epilepsia. 2008; 49 (Suppl. 1): 3-6.

5. Perucca E, Tomson T. The pharmacological treatment of epilepsy in adults. Lancet Neurol. 2011; 10: 446-56.

6. Hixson J. Stopping Antiepileptic Drugs: When and Why? Current Treatment Options in Neurology. 2010; 12: 434-442. 
7. Camfield P, Camfield C. When is it safe to discontinue AED treatment? Epilepsia. 2008; 49 (Suppl. 9): 25-28.

8. Glauser T, Ben-Menachem E, Bourgeoiset B, et al. ILAE Treatment Guidelines: Evidence-based Analysis of Antiepileptic Drug Efficacy and Effectiveness as Initial Monotherapy for Epileptic Seizures and Syndromes. Epilepsia. 2006; 47(7): 1094-1120.

9. J. A. French, A. M. Kanner, J. Bautista, et al. Efficacy and tolerability of the new antiepileptic drugs I: Treatment of new onset epilepsy: Report of the Therapeutics and Technology Assessment Subcommittee and Quality Standards Subcommittee of the American Academy of Neurology and the American Epilepsy Societ Neurology. 2004; 62: 1252-1260.

10. J. A. French, A. M. Kanner, J. Bautista, et al. Efficacy and tolerability of the new antiepileptic drugs II: Treatment of refractory epilepsy: Report of the Therapeutics and Technology Assessment Subcommittee and Quality Standards Subcommittee of the American Academy of Neurology and the American Epilepsy Society.

11. National Institute for Health and Clinical Excellence. The epilepsies: the diagnosis and management of the epilepsies in adults and children in primary and secondary care (update). (Clinical guideline 137.) 2012. http://guidance.nice.org.uk/CG137.

12. Beydoun A, D'Souza J. Treatment of idiopathic generalized epilepsy - a review of the evidence. Expert Opin Pharmacother. 2012; 13(9): 1283-98.

13. Bourgeois BF. Chronic management of seizures in the syndrom es of idiopathic generalized epilepsy. Epilepsia. 2003; 44 Suppl 2: 27-32.

14. S. Noachtar, E. Andermann, P. Meyvisch, F. Andermann, W. B. Gough, J. Schiemann-Delgado, Levetiracetam for the treatment of idiopathic generalized epilepsy with myoclonic seizures Neurology. 2008; 70(8): 607-616.

15. Perucca E. Pharmacological and therapeutic properties of valproate: a summary after 35 years of clinical experience. CNS Drugs 16, 2002; 695-714.

16. Marson A.G, Al-Kharusi A.M, Alwaidh M, Appleton R, Baker G.A, et al. SANAD Study group, 2007. The SANAD study of effectiveness of valproate, lamotrigine, or topiramate for generalised and unclassifiable epilepsy: an unblinded randomised controlled trial. Lancet. 369, 1016-1026.

17. Gelisse P, Genton P, Kuate C, Pesenti A, BaldyMoulinier M, Crespel A. Worsening of Seizures by Oxcarbazepine in Juvenile Idiopathic Generalized Epilepsies. Epilepsia. 2004; 45: 1282-1286. 1. 1.

18. Thomas P, Valton L and Genton P. Absence and myoclonic status epilepticus precipitated by antiepileptic drugs in idiopathic generalized epilepsy. Brain. 2006; 129, 1281-1292.

19. Lige Liu, Thomas Zheng, Margaret J. Morris, Charlott Wallengren, Alison L. Clarke, Christopher A. Reid, et al. The Mechanism of Carbamazepine Ag- gravation of Absence Seizures. The Journal of Pharmacology and Experimental Therapeutics. 2006; 319: 790-798.

Резиме

:
$;$
милиј ветковск, гор узм новски,
ој н ошковски

Универзитетска клиника за неврологија, Медицински факултет, Универзитет „Св. Кирил и Методиј“, Скопје, Р. Македонија

Студијата беше направена со цел да се процени клиничката практика во однос на фармаколошкиот третман на епилепсиите меѓу невролози во Република Македонија. Анкетниот лист, составен од 15 прашања, беше испратен до 30 невролози; беа добиени одговори од 24 (80\%). Половина од испитаниците би ординирале антиепилептична терапија по прв неиспровоциран напад во зависност од наодите на ЕЕГ и МНР, додека останатите би го одложиле третманот до евентуален втор напад. Прекинот на антиепилептичната терапија треба да е индивидуализиран. „Карбамазепин“ и „ламотригин“ се најчесто препишувани лекови за парцијални напади, а вториот избор вклучува голем број класични антиепилептици и антиепилептици од новата генерација. За генерализирани тонично-клонични напади, апсанси, миоклонични, мешани или некласифицирани напади, најчесто е ординиран „валпроат“. Истражувањето покажа дека изборот на антиепилептична терапија е во согласност со актуелните ставови за спектарот на ефикасноста на одделни лекови кај различни видови напади. Сепак, некои од резултатите сугерираат потреба од понатамошна и континуирана едукација на невролошката заедница за антиепилептичната терапија.

лучни зборови: невролог, анкета, епилепсија, фармаколошки третман, антиепилептични лекови. 